\title{
The effects of monetary policy on house prices in Spain: the role of the economic and monetary union membership in the housing bubble prior to the great recession
}

\author{
Tibor PÁL
}

\section{AGH University of Science and Technology, Poland}

\begin{abstract}
:
Aim: This paper aims to discover the evolution of monetary transmission in Spain by focusing on the short-term interest rate, credit aggregates and house prices through different stages of economic development and European integration between 1975 and 2008. In addition, the analysis devotes special attention to the interval of the last housing boom, in order to reveal the importance of the interest rate policy of the ECB.

Design / Research methods: The study applies a tri-variate autoregressive model assigned to three overlapping periods outlined by regime shifts in the Spanish economy. The estimation output determines the strength and persistency of the links between interest rates, credit aggregates and house prices. Consequently, the results of the econometric analysis provide proper base for comparison in order to identify the dominating channels of monetary transmissions through a prolonged period.
\end{abstract}

Conclusions / findings: It is found that the transmission mechanism in Spain essentially altered over time since 1975. At the beginning of the full analysed interval the role of the credit channel was dominant, then its importance gradually diminished. After the EMU accession the traditional interest rate channel became the leading factor with an intensified and more persistent effect on house prices.

Originality / value of the article: While there are numerous researches aimed at estimating the impact of monetary policy on the real economy, empirical studies focusing exclusively on the link between interest rate policy and house prices in Spain are still rare. As the present paper concentrates solely on the Spanish characteristics through extended interval, the study provides country-specific inferences.

Implications of the research: Understanding the mechanism of the monetary policy effects on the housing sector is an essential aspect of designing policy interventions aimed at keeping house price development in check.

Limitations of the research: Despite the significant results of the empirical analysis, the excessively dynamic increase in the property prices suggests that the factor of irrational expectations also played important role in the latest Spanish housing bubble.

Key words: Monetary policy, VAR, ECB, Housing boom, Monetary transmission mechanism JEL: E52, E58.

Correspondence address: AGH University of Science and Technology, Antoniego Gramatyka 10, 30-962

Kraków, Poland. E-mail: tiborpal@outlook.com

Received: 10-09-2017, Revised: 19-02-2018, Accepted: 20-02-2018

doi: http://dx.doi.org/10.29015/cerem.540 


\section{Introduction}

The latest nationwide housing bubble in the United States, which was a crucial conditional factor of the subsequent global financial crisis (GFC) of 2008, was not unique: at that time most advanced economies experienced substantial expansion in the residential investment sector and among them the Spanish housing boom was outstanding.

Fitting into the global economic trend, the accompanying prosperity was also prominent: the country experienced a more than a decade long sustained economic expansion together with a dynamic growth in residential investment, private consumption and credit aggregates.

The exceptional economic prosperity was the fruition of the preceding socioeconomic transition along with the European integration from the 1970s onward by passing through multiple regime shifts. After the onset of the democratic transformation initiated by the end of the Franco era from 1975 onwards, the process of European integration was brought forward by joining the European Union (EU) in 1986. Yet, the accession to the European Monetary Union (EMU) in 1999 most certainly represents a milestone in the country's economic history.

In almost fifty years, from being an underdeveloped country until the midtwentieth century, Spain reached an important position on the global stage. In 2007 it turned into the 13th largest economy in the world according to its total GDP and it became a member of the 22 countries with the highest output per capita in the world: the GDP at current prices increased from 169.1 billion dollars in 1975 to 1474 billion in 2007, that is, the production multiplied by near 9 times in 27 years (OECD, nd.). Parallel with the progressive growth, the economic environment gradually became more favourable as well: the yearly inflation rate steadily dropped from the moderntime documented highest peak of 27.2 experienced in 1977 to below 10 percent at the time of the EU accession with a further decrease onward to around 3 percent. In addition, the short-term interest rate fell from its historical peak of 26.1 percent recorded in 1978 to below 8 percent in 1994, when the national central bank (Banco de España) became independent and afterwards - due to the scheduled Spanish convergence to the monetary union - the rate dropped below 3 percent in 1999 
(OECD, nd). Graph 1 demonstrates the historical evolution of the inflation level together with short-term interest rates by representing three intervals outlined by the main regime shifts: the 'Moderation' accounts for the period from the beginning of the Spanish democratic transition to the EMU accession, the 'Exuberance' stands for the interval from the EU accession to the beginning of the GFC and finally the 'Euro Era' accordingly focuses solely on the EMU period. It is conspicuous from the illustration that the level of the two indices was steadily decreasing with diminishing volatility through the analysed intervals.

It is important to note that the EMU accession not only entailed the adoption of a common currency and a single monetary policy administered by the ECB but it introduced the country to an integrated financial environment as well, where the obstacles of capital flows became substantially relaxed. As a result, the country experienced a massive capital inflow which also contributed to the domestic housing surge. ${ }^{1}$ Furthermore, the gradual deregulation process on the mortgage market from the 1980 s onwards $^{2}$ extended the space for the intensified housing demand ${ }^{3}$. The introduction of securitization in 1992 by the Law of Securitization Vehicles and the further deregulation in 1998 also improved the mortgage credit activity by allowing banks to finance a large portion of bank landing (Carbó et al. 2011). These improvements with the important landmark of EMU accession also verify the designation of the multiple phases in the Spanish economic progress.

The housing sector in Spain has been traditionally accounted as a leading factor for supporting the economic prosperity. Similarly, the majority of experts argue that the housing demand was the main engine of the latest Spanish economic expansion (e.g. Esteban, Altuzarra 2008; Palomera 2013; Rodríguez 2016; Navarrete 2016).

\footnotetext{
${ }^{1}$ Cuestas (2017) found evidence for positive relationship between house prices and foreign capital inflow by substituting the amount of mortgage credit by changes in net foreign assets in his VAR model.

${ }^{2}$ The mortgage bond issuance had been monopolized by the Spanish Public Mortgage Bank until 1981 when the Mortgage Market Act, which authorized commercial banks to grant mortgages and extended both their length and the maximum legal loan-to-value percentage, gave the first prominent impetus toward the deregulation process (Palomera 2013).

${ }^{3}$ Palomera (2013) emphasizes that the credit easing was also promoted by the ECB.
} 
The empirically correlated business cycles with the house price fluctuations ${ }^{4}$ offer a reason for the critical scrutiny of the mechanism of monetary policy in the context of the housing market and the connected intermediate lending activity through this period. Therefore, a systematic analysis of the links between the three variables through the different stages of the European integration can provide a better insight into how the interest rate policy operated in the property sector.

\section{Graph 1. Historical development in short-term interest rates and inflation level}

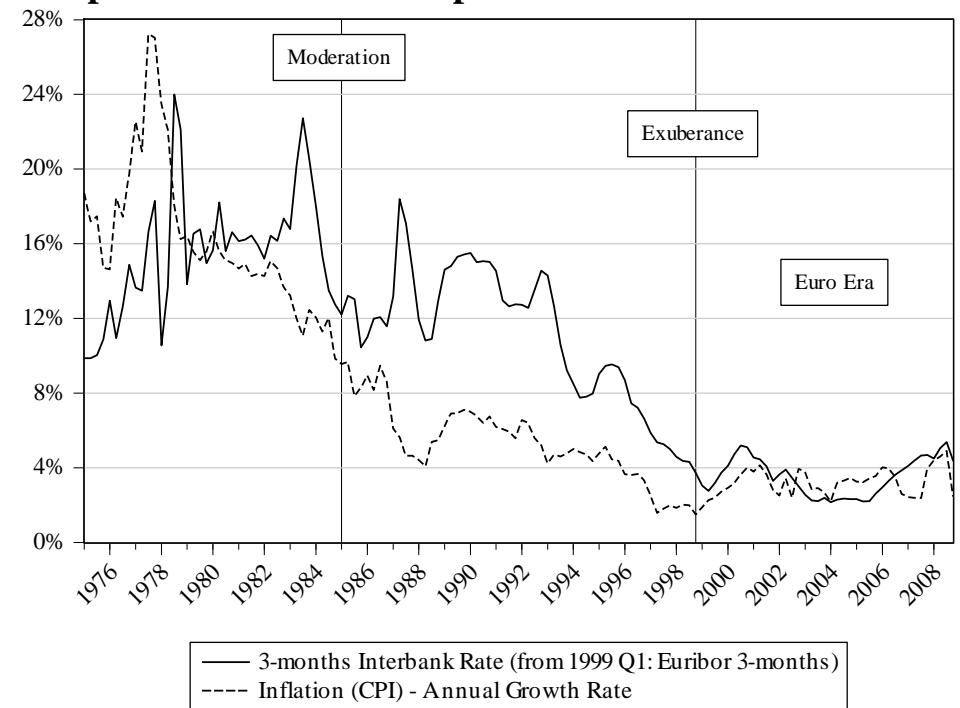

Source: OECD, own editing.

By focusing on the house price development through the above introduced phases of the Spanish progression, the aim of the article is twofold. First, it attempts to explain the development of the house prices in the context of the monetary transmission mechanism and to measure its responsiveness to the interest rate policy. Second, by focusing solely on the period of the last housing bubble, an estimation is made to discover the role of the European Central Bank's (ECB) interest rate policy in the Spanish residential boom. To answer these questions, I conduct an analysis

\footnotetext{
4 The generic causality between asset-market behaviour and the real economy is explored by for example Fisher (1933); Bernanke, Gertler (1995); Bernanke et al. (1996); Higgins, Osler (1997); Case et al. (2001) and Iacoviello (2005).
} 
using a tri-variate Vector Autoregressive Model (VAR) to expose the multidirectional interlinkage between the main engines of the considerable expansion of the Spanish economy. The econometric approach applied in the study is in line with Goodhart and Hofmann (2008), Bjørnland and Jacobsen (2010), who aimed at discovering the role of house prices and credit growth in the economic activity in European countries. ${ }^{5}$ Furthermore, Ciccarelli, Maddaloni and Peydró (2013) estimate the impact of the ECB's monetary policy on aggregate output through different time horizons including credit aggregates in their model. Although I use a similar econometric methodology, there are some significant differences. On the one hand, the VAR model employed in the study focuses solely on the Spanish economy in order to gain country-specific inferences in accordance with the purpose of the paper. On the other hand, as the central concern of the paper is the impact of monetary policy on house prices, the VAR model excludes the variables connected to output and consumption.

Accordingly, the central research hypothesis can be expressed in the following way. In parallel with the European integration and economic developments, the monetary transmission channels influencing house prices altered and the low interest rate environment brought by the Eurozone accession significantly contributed to the evolution of the housing boom which later transformed into a housing bubble.

The paper is organized as follows. In the next section, a survey on the monetary transmission mechanism with a literature review is performed, focusing on the three variables which constitute the subsequent econometric analysis. In Section 3, the data analysis and the applied methodology are presented together with the VAR outputs. Finally, Section 4 presents the main econometric results harmonized with the connected macroeconomic theories. The article ends with the conclusion.

\footnotetext{
${ }^{5}$ Goodhart and Hofmann (2008) use panel VAR for 17 industrialized countries (including Spain) in the period of 1970-2006, Bjørnland and Jacobsen (2010) analysis focus on Norway, Sweden and the UK.
} 


\section{Overview of the monetary transmission mechanism from the real estate perspective}

Before exploring the effects of monetary shocks on the property market in Spain, it is appropriate to put housing in a theoretical and empirical framework of monetary economics developed until today. This section is aimed at summarizing these findings by connecting the interest rate policy (as it represents the primal instrument of monetary policy ${ }^{6}$ ) and financial intermediates (as it represents the channels associated with the financial market imperfections applied in non-neoclassical monetarist view ${ }^{7}$ ) with house price alterations.

After an extended period with a marked importance on the non-monetary features of business cycles, from the late 1980s onwards academic focus drifted to the evaluation of monetary policy in the short-term course of the real economy. As a result, a broad consensus has been reached: the significant role of the monetary policy in regulating economic activity became apparent (Romer, Romer 1989; Bernanke, Blinder 1992; Bernanke, Gertler 1995; Clarida et al. 1999). Yet, the certain way how monetary policy operates and filters into the real economy is still not universally accepted. Consequently, the academic discourse on the prediction and evaluation of monetary shocks gained a constant ongoing progress and to model the transmission of monetary policy is a crucial subject in a broad spectrum of empirical research. These studies generally revolve around a foundation of two central concepts: the conventional perception (generally corresponds to the neoclassical view) where financial markets are perfect and the more advanced credit view, which grounded on the implications of financial market imperfections. ${ }^{8}$ Despite the evidence that these concepts are, to various extents, operationally connected and possibly reinforce each other, the following section is aimed at an orderly alignment of the relevant theoretical models tied with the most relevant empirical findings.

\footnotetext{
${ }^{6}$ As for example Clarida, Galí and Gertler (1999) argue, the conventional practice is designating shortterm interest rate as the main monetary policy tool in macroeconomic models. Brayton and Ambrose (1990), McCallum and Nelson (1997), Goodfriend (2007), Taylor (1995) also consider interest rate policy as the key monetary policy instrument.

${ }^{7}$ Bernanke and Gertler (1995) underline and explain the relevancy of the corresponding credit channels in details.

${ }^{8}$ Boivin et al. (2010) classify their findings based on the framework of neoclassical and nonneoclassical views.
} 


\subsection{Conventional interest rate channels}

In conventional theories interest rates and asset prices play the principal role in the course of economic movements induced by central banks' monetary policies. The most traditional way of monetary transmission mechanism is based on the standard neoclassical model, which is associated with the direct relationship between interest rates and the user cost of capital. (Jorgenson 1963; Bernanke, Gertler 1995; Boivin et al. 2010). Even though in early studies the model was applied prominently to business decisions about investment spending, later findings revealed that households' spending on consumer durable and housing expenditures also construe investment decisions ${ }^{9}$ (Mishkin 1996). The connection between the short-term interest rate and house prices through the altered cost of capital implicates further dimensions to be revealed. Firstly, it is the real rather than the nominal interest rate which influence investment decisions (Modigliani 1971). From this aspect, Boivin, Kiley and Mishkin (2010) emphasize that the direct link between nominal and real rates is ensured by the concept of nominal wage and price rigidities, primarily framed by Keynes (1936). Second, as the long-life feature of real estate investments implies extended financial view, it is rather the long-term interest rate which determines these expenditures (Bernanke, Gertler 1995). However, according to the expectation hypothesis which states that the long-term real interest rate is based on the expected future short-term rates, the policy decisions about nominal interest rates eventually determine the real long-term interest rates which have a major impact on residential housing investments (Taylor 1995).

The other influential interpretation of movements in asset prices associated with interest rate changes supported by the model of Tobin (1969). The key nexus in this concept is the ratio, denoted as Tobin's $q$, which is originally defined by the market value of firm' assets divided by its replacement cost. The ratio higher than 1 activates investments as the expected profit of the firm exceeds the cost of assets. When applied to residential investment decisions, the ratio equals the property prices divided by the corresponding replacement cost. Lower interest rate heightens the ratio through decreasing cost of capital represented by lower construction costs.

\footnotetext{
${ }^{9}$ In this study the term "housing investment" refers to housing purchases made by both firms and households.
} 
Additionally, at the time of house price appreciations, the higher numerator further rises the ratio. Based on these relations the higher ratio stimulates real estate investment activity. From this aspect, Goodhart and Hofmann (2008) emphasise that the increase in property prices relatively decreases the construction costs thus residential investment becomes more profitable. The positive reaction of residential investment on inflated house prices again amplifies housing demand thus augments its price level.

The alternative way to connect Tobin's q to the cost of capital approach is to discover the link between stock prices and investment spending. The elevated stock prices induced by lowered interest rate implies relatively low cost of new capital hence it triggers new investments (Boivin et al. 2010). This channel, through higher q can make housing investment more attractive and thereby stimulate the residential investment, especially during the time of a housing boom. As Gattini and Ganoulis (2012) emphasize the key role of residential investment in house price development for both new and existing homes, the importance of Tobin's q cannot be neglected regarding housing booms.

Another appearance of interest rate effect on house prices is the wealth channel. It operates through the intertemporal consumption ${ }^{10}$ which is affected by the net wealth condition of households (Hunter et al. 2003). Since the essential component of households' assets in Spain is housing wealth, ${ }^{11}$ a rise in its price level increase their lifetime resources hence it shifts their consumption plans, which may embrace house purchase as well. ${ }^{12}$ From this perspective, Boivin et al. (2010) also maintain that standard life-cycle wealth effect is a relevant factor in the monetary transmission mechanism. In their paper they emphasize that lower short-term interest rates can shift demand for housing, thus increasing its price, as lower interest rate implies lower discount rate applied to the income flows related to properties. The following

\footnotetext{
10 The connected theory is based on the life-cycle model of consumption first developed by Modigliani and Brumberg (1955) and later advanced by Ando and Modigliani (1963) and also the permanent income hypothesis by Friedman (1957).

${ }^{11}$ According to the Spanish Survey of Household Finances (Encuesta Financiera de las Familias) the share of real estates in households' wealth was 70.9 percent in 2002, furthermore Goodhart and Hofmann (2001) also emphasize the strong wealth effect originated from house price appreciation as housing wealth is an important factor in private sector wealth.

${ }^{12}$ For example, Esteban and Altuzarra (2008), and Romero (2014) shows relatively high propensity for second home purchases in Spain.
} 
increase in aggregate wealth then prompts household consumption. Mishkin (1996) also demonstrates that monetary policy via Tobin's q together with the wealth channels in relation to housing price can stimulate property market.

Besides the above demonstrated traditional ways of causalities, demand for housing can be influenced by expectations steered by expansionary (or contractionary) monetary policy as well. Trichet (2003) argues, that changes in interest rates can modify people's outlooks about future economic growth and income expectations which in turn can impact housing expenditures. The elevated property prices are able to reinforce the operation of the expectation channel and give further impetus for house price inflation. The operation of this factor is especially enhanced during the real estate boom as the positive outlook can contribute to the acceleration of increasing house prices. ${ }^{13}$ Boivin at al. (2010) also demonstrate the importance of expectation in transmission mechanism through several channels. The key link is the impact of monetary policy on expected short-term interest rates which can support the channel of user cost of capital. ${ }^{14}$ Furthermore, they also underline the role of inflation expectations which together with the expected future course of shortterm interest rates influence the real interest rates. ${ }^{15}$

\subsection{Credit channels}

Despite Taylor (1995) having proved that the traditional interest rate channels play the leading role in the fluctuation of consumer and investment spending, Bernanke and Gertler (1995) suggest that the driving force of interest rate on investments and consumptions is exaggerated in the conventional estimates. Surprisingly, their empirical results indicate large and rapid inverse response in house expenditures for interest rate policy shifts. Considering that durable investments (such as housing) are more likely to be dependent on long-term interest

\footnotetext{
${ }^{13}$ The academic research on the role of expectation in housing cycles are considerably broad and it is analysed from different angels, for example Shiller's various works embrace comprehensive discussion on the relevancy and mechanism of (irrational) expectations during housing booms, also Hunter, William and Kaufman's (2003) collection of surveys provides excellent orientation on the topic.

14 The key role of expectation in the user cost of capital channel is explained by Case and Shiller (2003).

${ }^{15}$ Boivin et al. (2010) argue that it is rather the long-term than the short-term interest rates which drive investments.
} 
rates (Taylor 1995) and the notion that monetary policy should have weaker effect on long-term rates (Bernanke, Gertler 1995), the above findings propose an additional function of transmission mechanism, that is, the credit channel.

The perception that credit markets may have an important role in the movement in the real economy is not recent: Fisher (1933) considered the distressed banking system as a leading factor causing severity of the Great Depression. The reemergence of the subject in the seminal work of Bernanke (1983), which analyses the impacts of the financial crisis on the real costs of the credit markets, opened a new discussion on the role of financial frictions in monetary mechanisms. Bernanke and Gertler (1995) provide a detailed review of the way credit market imperfections can modify the effects of the monetary policy in a real economy. ${ }^{16}$ In their study they refer to the credit channel as a "set of factors that amplify and propagate conventional interest rate effect". Therefore, this process is not an independent but rather a complementary factor of the conventional interest rate channel which evolves on two principal ways: balance sheet channel and bank lending channel (Mishkin 1995).

The source of the balance sheet channel is the principal-agent problem, more precisely the adverse selection ${ }^{17}$ and moral hazard, which stem from the asymmetric information between lenders and borrowers (Mishkin 1995). According to Bernanke and Gertler (1995) it materialises as an external finance premium (the difference between the cost of external funds and the opportunity cost of internal funds), which reflects the cost associated with the agency dilemma. This problem persists particularly in the mortgage scheme which typically involves high uncertainty by its nature (Ambrose et al. 2016).

There are multiple aspects how balance sheet alteration can be approached, among them the most direct way is represented by the change in the net worth. In our setting, net worth corresponds to the price of real estates, used as collateral, which

\footnotetext{
${ }^{16}$ See also paper of Bernanke and Blinder (1992) where their empirical analysis presented substantial evidence that monetary policy has significant impact on loan activity which further influence the real economy, similarly Hubbard (1995) in his survey on credit channel of monetary policy also argues that models based on financial constrains verify the significant effect of monetary policy beyond the conventional interest rate channels and Harris et al. (1994) survey on the credit crunch effect on housing market.

${ }^{17}$ For further studies on adverse selection problems see Akerlof (1970) and Stiglitz and Weiss (1981).
} 
alters the borrowing capacity through varying the loan-to-value (LTV) ratio. Thus, the extended (reduced) availability of credit stimulate (hamper) not only the aggregate consumption but also housing demand which eventually push upward (downward) house prices. It is important to see that the course of the process may generate a positive feedback loop as the value of the property operates as a collateral in the mortgage activity. This endogenous pro-cyclical course in borrower's balance sheets can intensify and stimulate housing cycles, as similarly business cycles, a phenomenon termed "financial accelerator". ${ }^{18}$ Mishkin (1996) also points out that low policy rate implies higher equity prices which increases net worth of firms and again leads to a higher investment spending and aggregate demand. The key motive in the process is the perception that the higher the net worth of firms or households, the less severe the adverse selection and moral hazard problems in lending activity, which implies credit expansion. Ludwig and Sløk (2001) also argue that in the case of elevated house prices, the homeowners are able to realize equity in the form of refinancing of the house which has a positive impact on private investments.

The other alternative direction of interest rate socks implies its direct impact on borrowers' cash flow. The rising interest rates involves mounting interest expenses in short-term or floating-rate debt contracts which weakening borrowers' financial positions by reducing their cash flows (Bernanke, Gertler 1995). Mishkin (2010) specifically emphasizes the important role of real estate prices in monetary transmission mechanism. In his paper he demonstrates, that monetary policy by lowering interest rate has a direct effect on housing expenditure by means of decreasing financial costs connected to borrowing. He also underlines that the shortterm interest rate is more relevant than long-term since the short-term interest rate has a larger effect on firms' cash flow. It follows that in this approach the policy rate has a more direct influence on business and consumer behaviour. Boldin (1994) empirically linked house prices and funds rate by a measure of mortgage burden (a ratio of mortgage payments to income) on typical household's balance sheet in US and found convincing evidence of policy rate effect on house prices. This approach

\footnotetext{
${ }^{18}$ For more detailed review on the topic see Bernanke, Gertler and Gilchrist $(1996,1999)$ also see earlier surveys by Fisher (1933) and Minsky $(1964,1975)$ identifying financial factors corresponding accelerator processes in the real economy, Kiyotaki and Moore (1997) also emphasize the role of accelerator effect in relation to asset values and lending activity.
} 
provides further explanation why house prices have sharp response to monetary policy changes despite the presumably weak connection between interest rate policy and long-term real interest rate (Bernanke, Gertler 1995). Bjørnland and Jacobsen (2010) in their multi-country analysis found evidence of strong and prolonged impact of monetary policy on house prices which they explain by the cash flow effect on households' balance sheet as well.

The third way how balance sheet of firms and households can be impacted is the liquidity effects. Mishkin (2001) emphasize the role of liquidity channel in connection with consumer durable and housing expenditures steamed from their illiquid features. The specific nature suggests that as a response for expected financial distress, real estate investments became less desirable, as trading of durable goods in limited time mostly implies additional loss on the seller side. Similarly, housing demand is stimulated when households or firms are more relaxed about the economic prospects as financial position became more secured and menace of financial distress is diminished (Boivin et al. 2010). In contrast, Souse (2010) based on his VAR model concludes that a positive interest rate shocks induce flights toward less liquid but high earning assets. Souse finding suggests that there is a reverse function of liquidity effect on house prices which makes the total effect ambiguous.

Apart from the balance sheet effects, interest rate policy may also shift the supply of intermediate loans, which impact the credit activity thus influence the real economy. In this way of causality, labelled as bank lending channel, monetary contraction can influence banks' ability to lend (Hubbard 1995). As a result, borrowers reliant on external founds are exposed to higher financial premium or decline in credit flows. Bernanke and Gertler (1995) suggest that the operation of bank landing channel in US mortgage market was more relevant before $1980 \mathrm{~s}^{19}$ and assume that it has most likely diminished over time parallel with the trend of financial deregulations and innovations.

\footnotetext{
${ }^{19}$ Prior 1980s ceilings on deposit rates were in effect in US credit market referring the phenomenon called "disintermediation".
} 
The effects of monetary policy on house prices in Spain

\section{Empirical analysis}

Sims (1980) in his seminal work pointed out that at the time the prevailing macroeconometric methodology based on a large system of equations had an inherent instability, rooted in its restrictive identification. To overcome the identification problem, he proposed an innovative solution: the application of vector autoregression (VAR). This approach became a conventional tool for interpretation of macroeconomic movements as a response for policy changes ${ }^{20}$ (Sargent, Sims 2011). Blanchard (2000) also argues that VAR models with its limited size deliver more transparent structure which under a minimal set of identification restriction can provide evidence for dynamic effects of economic shocks. One of the chief innovation of VAR approach is the inclusion of expectations as the variables included in the model not only depends on the lagged values of other variables in the set but its own past values as well. This feature of the VAR model given the possibly pertinent function of expectations in the course of housing cycles further strengthen the decision for its implementation. The application of VAR models is supported also by its flexibility and functionality for conducting multivariate time series analysis aimed at discovering dynamic relationships (Sims 1980; Stock, Watson 1994; Brooks 2008). Furthermore Greene (2002) and Bernanke and Gertler (1995) also underlines its efficiency in analysis of effects of policy changes and external impulses.

Due to the above reasons, VAR models are also frequently applied in studies incorporating property prices in relation of monetary policy. Bjørnland and Jacobsen (2010) use VAR models to discover the role of house prices in the monetary policy transmission mechanism in Norway, Sweden and the UK. They demonstrate through VAR impulse response function that house prices react immediately and strongly to monetary policy shocks. Souse (2010) investigates relation between monetary policy and asset market in the Eurozone by VAR. He finds strong and persistent response in housing wealth for monetary policy contraction. Goodhart and Hofmann (2008) explore linkages between money, credit, house prices and economic activity in

\footnotetext{
${ }^{20}$ Examples of some influential studies see Sims (1992) studied the impacts of monetary policy across five different economies discovering several common features but also some differences, Blanchard and Perotti (2002) analysed the economic reaction on spending, Galí (1999) estimated technology shocks against other shocks through a VAR analysis.
} 
industrialised countries between 1970 and 2006 by a panel VAR. Through a comparison of subsamples, they discover strong multidirectional link between property prices and monetary variables between 1985 and 2006.

In this paper the VAR model is aimed at estimating causalities between interest rates, house prices and credit aggregates furthermore measuring the direction, the strength, the persistence and the timing of the impact on variables as a reaction for shocks occurring in other series. Combining these results with the theoretical base presented in the preceding section, the empirical output is expected to identify the dominating channels of monetary transmission resulting house price developments through different time horizons between 1975-2008. Following the purpose of the study, estimations were made on three different intervals which provide solid base for comparisons and interpretations.

The first analysed interval accounts for the period of 1975 Q1 until the last quarter before EMU accession - 1998 Q4. The interval was titled as "Moderation" (MP) since during this period the short-term interest rate dropped significantly and its volatility lowered. Furthermore, the inflation rate was also following a downward tendency during this time. The second analysed interval covers the period of 1985 Q1 until 2008 Q2. The reason for setting the beginning of the interval to 1985 Q1 is prominently the timing of EU accession but it is supported by the fact that from this time the real values of house prices and credit aggregates begin to increase intensively (Figure 2). Consequently, the period was named "Exuberance" (EP), which also refers to the two housing booms that occurred at the time. The last quarter of the period is set by the beginning of the GFC which also represents sharp structural breaks in the time series. The third analysed period is applied only from the time of Eurozone accession - therefore titled "Euro era" (MU) - till the burst of the housing bubble in the middle of 2008. Since the number of observations is low on a quarterly basis in this relatively short interval, I decided to use monthly data for the estimation in this period. The end of the monthly interval was set to the fourth month of 2008, according to the structural breaks in the series of house prices and the outstanding level of credit as reflected by the beginning of the recession. Figure 2 and Figure 3 demonstrate the development in house prices and the credit aggregates through the analysed interval. 
Graph 2 shows the nominal house price index (HPI) and real house price index (RHPI) together. It is clear that, while the nominal house price index increased continuously until 2008, the deflated value of the index was moving in a relatively narrow interval - except for the boom between 1986 Q1 and 1991 Q4 - until 2001 Q1 when the index started to rise significantly. Graph 3 plots the long-term volume of outstanding credit to the private sector in nominal and real term. The beginning of the notable increase in the real value occurred around the time of Spanish accession to the Eurozone. From this perspective, it is rational to use the values in real terms as this also supports the decision on the selection of the two analysed periods separated by the date of the Euro accession.

\section{Graph 2. Nominal and real house price index $(1975$ Q1 - 2013 Q3)}

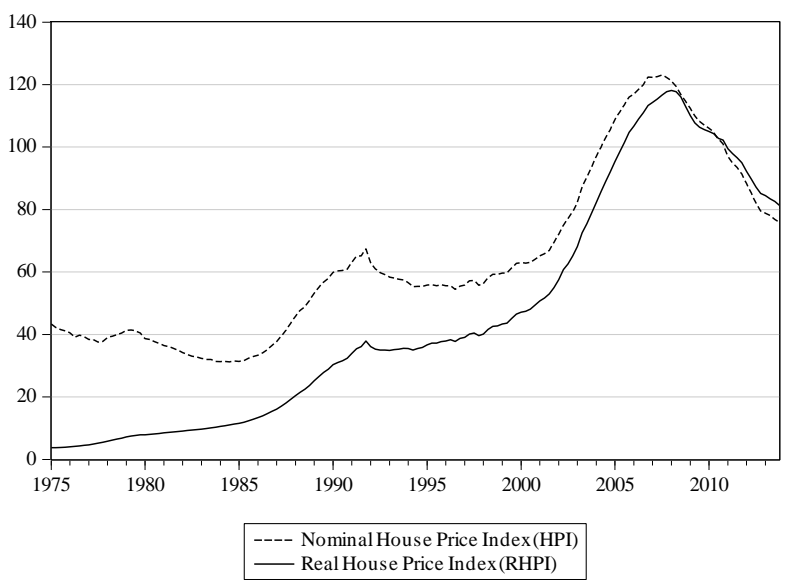

Source: International House Price Database of Federal Reverse Bank of Dallas, own editing. 


\section{Graph 3. The outstanding aggregate nominal and real credit to private sector in million EUR (1975 Q1 - 2013 Q3)}

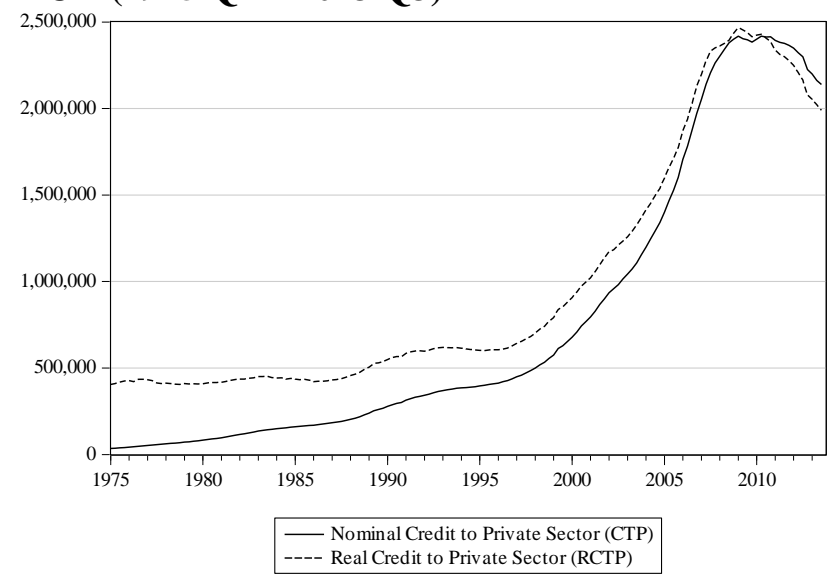

Source: Bank for International Settlements, own editing.

\subsection{Data and analysis}

The set of data series applied in the empirical analysis comprises short-term nominal interest rates, ${ }^{21}$ real house price indexes and real credit aggregates ${ }^{22}$. Except for the short-term nominal interest rate all data have been seasonally adjusted individually using the Census X12 procedure (Findley et al. 1998). The residential House Price Index (HPI) has been collected from the International House Price Database of Federal Reserve Bank of Dallas. ${ }^{23}$ The index is deflated by Consumer Price Index (CPI) in order to reach the real term of the values. ${ }^{24}$ Since house price data is not available in monthly frequency I used linear interpolation on house price data between quarterly observations for the interval of Euro era. ${ }^{25}$ The outstanding

\footnotetext{
${ }^{21}$ The short-term nominal interest rate is chosen to capture monetary-policy shocks. For similar reason, Bjørnland and Jacobsen $(2010,2013)$ use 3-month domestic interest rate (for European economies) and federal funds rate (for US economy) in their VAR model. Gimeno and Martinez (2010) also chose nominal interest rate and stress that the introduction of real interest rate in models with credit aggregates may poses problems.

22 Gimeno and Martinez (2010), Gerlach and Peng (2005) also deflate nominal values in their studies aimed at discovering relationship between nominal interest rate, property prices, and lending activity.

${ }^{23}$ The author acknowledges use of the dataset described in Mack and Martínez-García (2011).

${ }^{24}$ Following Bjørnland and Jacobsen (2010) who also used CPI for deflating nominal house price.

${ }^{25}$ In this procedure I followed the analysis of Ludwig and Sløk (2004) where linear interpolation was used to reach quarterly frequency from annual data.
} 
level of aggregate credit to private non-financial sector $^{26}$ (CTP) provided by all sectors of the economy (domestic banks, all other sectors and non-residents) on a quarterly basis was taken from the database of Bank for International Settlements (BIS, nd.). The series captures the outstanding amount of credit at the end of the reference quarter. In terms of financial instruments credit covers loans and debt securities. The series of credit aggregates on a monthly basis were taken from the database of Spanish National Statistics Institute (BDE, nd.). Both values are deflated by CPI respectively. The short-term interest rate is measured as the 3-Month or 90day Interbank Rates and the data was taken from the database of Organisation for Economic Co-operation and Development (OECD, nd.) for the interval prior to the date of Euro accession (1999 Q1). The series is completed with the 1-Month or 30day deposit rate for the period of 1975 Q1 to 1976 Q4 from the database of BDE (nd.). For the period after Euro accession the 3-Month Euribor rate was used and was taken from the Statistical Data Warehouse of European Central Bank (ECB SDW 2017). Both rates are based on the average of observations throughout the period of corresponding frequency. The series of CPI were taken also from the database of OECD in quarterly and on monthly bases.

\subsection{Econometric modelling}

In this paper I estimate a VAR model (Greene 2002) of the following form:

$$
y_{t}=\mu+C y_{t-1}+\varepsilon_{t}
$$

where $y_{t}$ is a vector of endogenous variables, $\varepsilon_{t}$ is a vector of errors and $\mu$ is a matrix of fixed effects. $C y_{t-1}$ is a matrix polynomial in the lag operator which is set by the multivariate generalization of Akaike's information criterion (AIC) considering lags up to four in order to determine the appropriate lag lengths. The vector of endogenous variables comprises the log difference of real house price index $(\Delta r h p i)$, the log difference of the real outstanding aggregate credit to private sector $(\Delta r c t p)$

\footnotetext{
26 The private non-financial sector includes non-financial corporations (both private-owned and publicowned), households and non-profit institutions serving households as defined in the System of National Accounts 2008.
} 
and the level of the short-term nominal interest rate $(\mathrm{si}){ }^{27}$

The vector $\mathrm{y}_{\mathrm{t}}$ is therefore given in the following way:

$$
y_{t}=[s i, \Delta r c t p, \Delta r h p i]^{T}
$$

A number of studies also advocate the choice for the VAR model applied to a single country. Jarociński and Smets (2008) applied a VAR model to the US economy solely in order to investigate the root cause of the developments in the housing sector with respect to the output and interest rate. Henceforth Camarero and Ordónez (2002) in their work analysed the monetary policy channels in Spain using a cointegrated structural VAR model and obtained significant results as well. Fernández and Hernández (2006) also estimated the effects of the exogenous fiscal policy in Spain in a VAR framework with relevant inferences.

The structure of the analysis according to Brooks (2008) is based on the following order. Firstly, the properties of the variants together with the diagnostics of the model are summarized. Then, the results of the model are represented: Granger causality, impulse function, and variance decomposition with the examinations of the three intervals respectively.

\subsection{Time-series properties and diagnostics}

In case of all intervals, the Augmented Dickey-Fuller (ADF) and the Kwiatkowski-Phillips-Schmidt-Shin (KPSS) statistical tests were conducted for determining stationarity. The ADF test according to Brook (2008) was applied with up to 12 lags. The $p$ values displayed in Table 1 for both ADF and KPSS tests suggest stationarity at the conventional 10 percent level.

\section{Table 1. ADF and KPSS statistical tests results}

\begin{tabular}{l|c|c|c|c|c|c}
\hline Statistical tests/Analysed Interval & \multicolumn{2}{|c|}{ Moderation Period } & \multicolumn{2}{c|}{ Exuberance Period } & \multicolumn{2}{c}{ Euro era } \\
\hline Times series & $\Delta$ rhpi & $\Delta$ retp & $\Delta$ rhpi & $\Delta$ retp & $\Delta$ rhpi & $\Delta$ rctp \\
\hline ADF p values & 0.0226 & 0.0221 & 0.0298 & 0.0963 & 0.0952 & 0.0000 \\
\hline KPSS p values & $>0.10$ & $>0.10$ & $>0.10$ & $>0.05$ & $>0.10$ & $>0.10$ \\
\hline
\end{tabular}

Source: Own computations.

${ }^{27}$ Goodhart and Hofmann (2008) also include the level of the short-term nominal interest rate in their VAR model, see also VAR models of Aspachs-Bracons and Rabanal (2010) or Dokko et al. (2011) with similar approaches. 
After evidence of stationarity of the time series the Lag Length Criteria was applied on the VAR models to set the number of relevant lags (Table 2). In the third interval, the criteria suggest 2 lag intervals however the LM test indicates autocorrelation at the third lag. In order to resolve this problem, I processed the VAR model with four lags and run the statistical tests again. The choice of four lags also supported by economic plausibility, as shocks in the economy presumably need longer time to unfold its impact. After adjustment in lag intervals there is no autocorrelation in the VAR model. To ensure that there is no serial correlation in the model the Autocorrelation LM test was applied.

\section{Table 2. Lag length criteria results}

\begin{tabular}{|c|c|c|c|}
\hline Criteria/Interval & Moderation Period & Exuberance Period & Euro era \\
\hline LR & 3 & 4 & 2 \\
\hline FPE & 4 & 4 & 2 \\
\hline AIC & 4 & 4 & 2 \\
\hline SC & 2 & 2 & 1 \\
\hline HQ & 3 & 3 & 1 \\
\hline
\end{tabular}

Source: Own computations.

Lastly the Stability Condition Check shows that there are no polynomial roots, which lie outside the unit circle.

\subsection{Empirical results}

According to the standard Wald Test (Table 3), which is a primal function of VAR models, in the first "Moderation" interval only the credit to private sector Granger causes the house price although it shows slight reverse impact as well. In the second "Exuberance" period the result documents similar structure of causalities however the strength of links is increased. In addition, the combined impact with short-term interest rate on credits became statistically significant. The leading factor remains the credit activity with near zero $p$ value and its mutual effect with the interest rate on the house prices also became more significant. Regarding the "Euro era", the 3-Month Euribor rate turns into the most relevant driving force in case of 
credit and house price developments. The outstanding credit only within the joint effect with the interest rate induces innovations in property prices.

The evaluations of Granger causality tests provide solid orientation about the statistically significant impacts of the variables on the future values in the model. Impulse responses demonstrate the responsiveness of the dependent variables in the VAR to shocks to each of the variables (Brooks 2008). The orthogonalized shocks of the model are based on a simple Cholesky decomposition ordered according to the previously discussed monetary transmission mechanisms. Even though the direction of the impact between credit activity and property prices is ambiguous and can evolve in both ways, I set up the order with preference to the borrowing cost approach - that is, the nominal interest rates primarily inversely affect the households' and firms' cash flow thus improving their ability to purchase properties. Runkle (1987) argues that the accurate interpretation of impulse responses is problematic and suggests the construction of confidence bands around the impulse responses. According to this, for each of the graphs, the plus/minus two standard error (95\%) confidence bands are applied respectively. As visible on the Graph 4, in each of the periods a shock in short-term interest rates had significant impact on the outstanding credit to private sector. Although its extent decreases chronologically, the responses are more consistent according to the confidence bands. Regarding the responses of credit aggregates to a shock in house price during the "Moderation" period, the reaction is positive but its magnitude is not significant according to the confidence bands. In the "Exuberance" period the power of responses is slightly larger and more relevant but in the Euro era the impact is ambiguous. The direct effects of the shocks on short-term interest rates in the first two intervals are not significant. However, focusing only on the Euro era, the graph displays a significant reverse impact in the first 15 months. While the responses of house prices to shocks in credit to private sector during the "Moderation" and "Exuberance" periods are significant until the fifth quarter, surprisingly in the Euro era there is no obvious relationship between the two variants. 


\section{Table 3. Granger causality test results}

\begin{tabular}{llll}
\multicolumn{5}{c}{ Moderation (MP) } \\
Sample: 1975Q1 1998Q4 \\
Included observations: 91 \\
\multicolumn{4}{l}{} \\
\hline Dependent variable: SI \\
\hline \hline Excluded & Chi-sg & df & Prob. \\
RCTP & 1.80773 & 4 & 0.77110 \\
RHPI & 2.34058 & 4 & 0.67340 \\
\hline \hline All & 4.13445 & 8 & 0.84480 \\
\hline \hline \multicolumn{4}{c}{} \\
\hline \hline Dependent variable: RCTP \\
\hline \hline Excluded & Chi-sg & df & Prob. \\
SI & 5.38012 & 4 & 0.25050 \\
RHPI & 7.58343 & 4 & 0.10810 \\
\hline \hline All & 11.89693 & 8 & 0.15590 \\
\hline \hline \multicolumn{4}{l}{} \\
\hline \hline Dependent variable: RHPI \\
\hline \hline Excluded & Chi-sg & df & Prob. \\
SI & 4.57173 & 4 & 0.33410 \\
RCTP & 10.92772 & 4 & $\mathbf{0 . 0 2 7 4 0}$ \\
\hline \hline All & 14.18647 & 8 & $\mathbf{0 . 0 7 7 0 0}$ \\
\hline \hline \multicolumn{5}{c}{} \\
\hline \hline
\end{tabular}

Exuberance (EP)

Sample: 1985Q1 2008Q3

Included observations: 91

\begin{tabular}{llll}
\hline \multicolumn{4}{l}{ Dependent variable: SI } \\
\hline \hline Excluded & Chi-sg & df & Prob. \\
RCTP & 0.97199 & 4 & 0.91400 \\
RHPI & 1.74270 & 4 & 0.78290 \\
\hline \hline All & 2.47671 & 8 & 0.96280 \\
\hline \hline
\end{tabular}

\begin{tabular}{llll}
\hline \hline \multicolumn{4}{l}{ Dependent variable: RCTP } \\
\hline \hline Excluded & Chi-sg & df & Prob. \\
SI & 5.99646 & 4 & 0.19940 \\
RHPI & 10.72466 & 4 & $\mathbf{0 . 0 2 9 8 0}$ \\
\hline \hline All & 13.98364 & 8 & $\mathbf{0 . 0 8 2 2 0}$ \\
\hline \hline
\end{tabular}

\begin{tabular}{llll}
\hline \multicolumn{4}{l}{ Dependent variable: $R H P I$} \\
\hline \hline Excluded & Chi-sg & df & Prob. \\
SI & 3.66591 & 4 & 0.45310 \\
RCTP & 19.61149 & 4 & $\mathbf{0 . 0 0 0 6 0}$ \\
\hline \hline All & 21.46498 & 8 & $\mathbf{0 . 0 0 6 0 0}$ \\
\hline \hline
\end{tabular}

Euro era (MU)

Sample: 1999M01 2008M04

Included observations: 108

\begin{tabular}{llll}
\hline \hline \multicolumn{4}{l}{ Dependent variable: EURIBOR } \\
\hline \hline Excluded & Chi-sg & df & Prob. \\
RCTP & 7.6493 & 4 & 0.10530 \\
RHPI & 15.2824 & 4 & $\mathbf{0 . 0 0 4 1 0}$ \\
\hline \hline All & 23.25305 & 8 & $\mathbf{0 . 0 0 3 1 0}$ \\
\hline \hline
\end{tabular}

\begin{tabular}{llll}
\hline \hline \multicolumn{5}{l}{ Dependent variable: RCTP } \\
\hline \hline Excluded & Chi-sg & df & Prob. \\
EURIBOR & 8.7683 & 4 & $\mathbf{0 . 0 6 7 2 0}$ \\
RHPI & 3.6532 & 4 & 0.45500 \\
\hline \hline All & 9.75984 & 8 & 0.28230 \\
\hline \hline
\end{tabular}

\begin{tabular}{llll}
\hline \hline \multicolumn{4}{l}{ Dependent variable: RHPI } \\
\hline \hline Excluded & Chi-sg & df & Prob. \\
EURIBOR & 11.2880 & 4 & $\mathbf{0 . 0 2 3 5 0}$ \\
RCTP & 2.1891 & 4 & 0.70100 \\
\hline \hline All & 14.86061 & 8 & $\mathbf{0 . 0 6 1 9 0}$ \\
\hline \hline
\end{tabular}

Source: Own computations.

Variance decomposition separates the variation in an endogenous variable into the combined shocks to the VAR. Accordingly, the variance decomposition provides information about the relative prominence of each random improvement in affecting the variables in the model. Therefore, the variance decomposition result is a gainful method to supplement the outputs of Granger causality and impulse response. The Graph 5 demonstrates the significant effect of short-term interest rates and house prices on credit aggregates in the first two intervals. However, their degree of contribution is different in the "Exuberance" period compared to the preceding interval. In the first period, the short-term interest rate had more influence over time with a linear increase reaching 20 percent after 12 quarters. The contribution of house prices is around 10 percent at the twelfth period with an increasing influence after the fourth quarter. In the "Exuberance" interval the proportion between the 
explanatory variables is changed. The influence of the short-term interest rate become weaker, reaching around 10 percent in the third year. Furthermore, the impact on house prices after one year turns out to be significant and after the sixth period its contribution is larger than that of the short-term interest rate.

\section{Graph 4. Accumulated impulse responses to Cholesky One S.D. Innovations} (MP, EP, MU)

Moderation (MP)

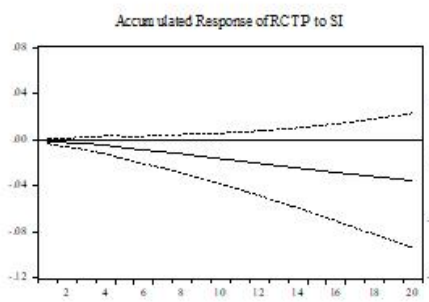

Accur ulated Response of $C T P$ to RHPI

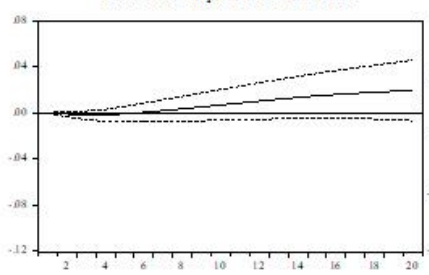

Accuro ulated Response of RHPI to SI

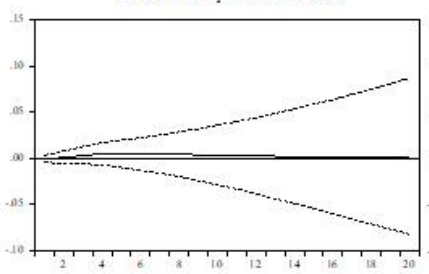

Accur ulated Respone of RHPI to RCT P

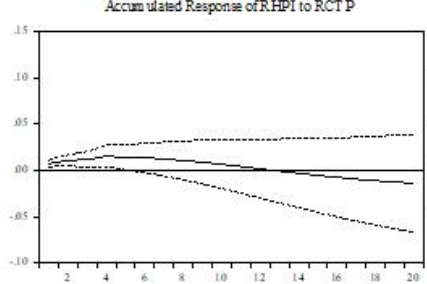

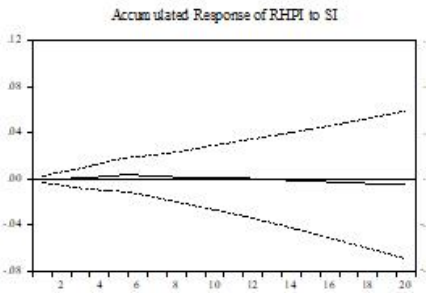

Accur ulated Response ofRHPI to RCT P

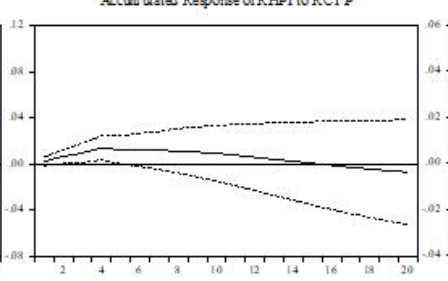

Euro era (MU)
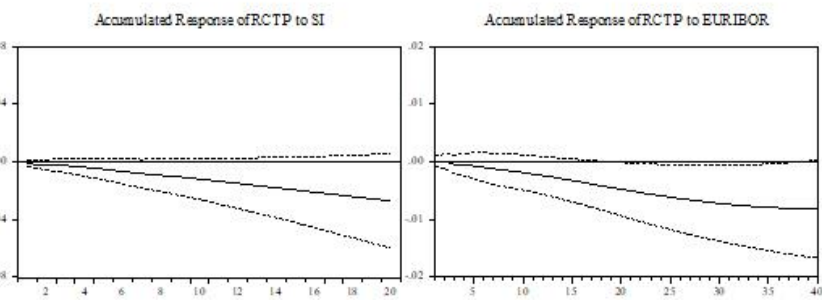

Accum ulated Response of RCTP to RHPI
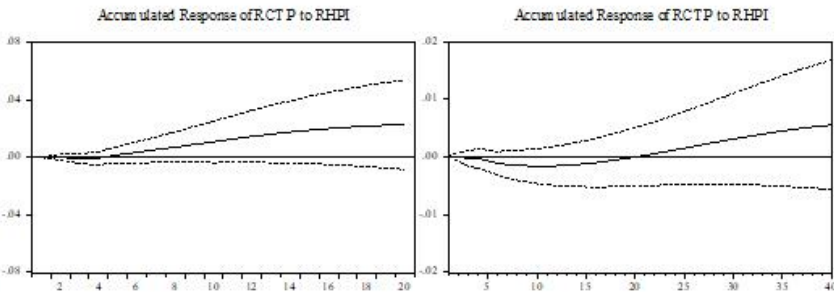

Accur ulated Response of RHPI to EURIB CR

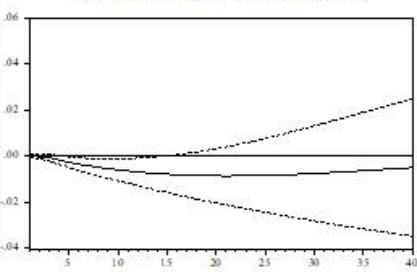

Accur ulated Response of RHPI to RCT P

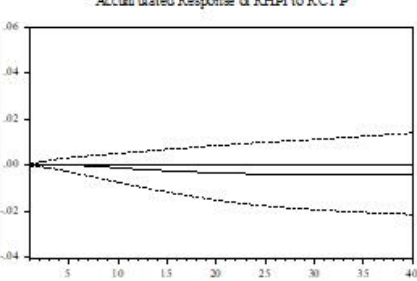

Source: Own computations. 
In the Euro era both interest rate and house price have less contribution to the improvement in the credit to private sector aggregate. After 3 years, the variation in the two explanatory variables only explains $10 \%$ of the variation in the total amount of credit. The results of variance decomposition of house prices provide interesting information. The development in property prices in both the "Moderation" and "Exuberance" periods is explained primarily by the change in private credit outstanding with milder contribution in the second interval. However, during the Euro era, the short-term interest rate become the major explanatory variable with reduced influence of credit activity. The impact of interest rate emerges in the first half year reaching the level of 20 percent.

\section{Graph 5. VAR variance decomposition (MP, EP. MU)}
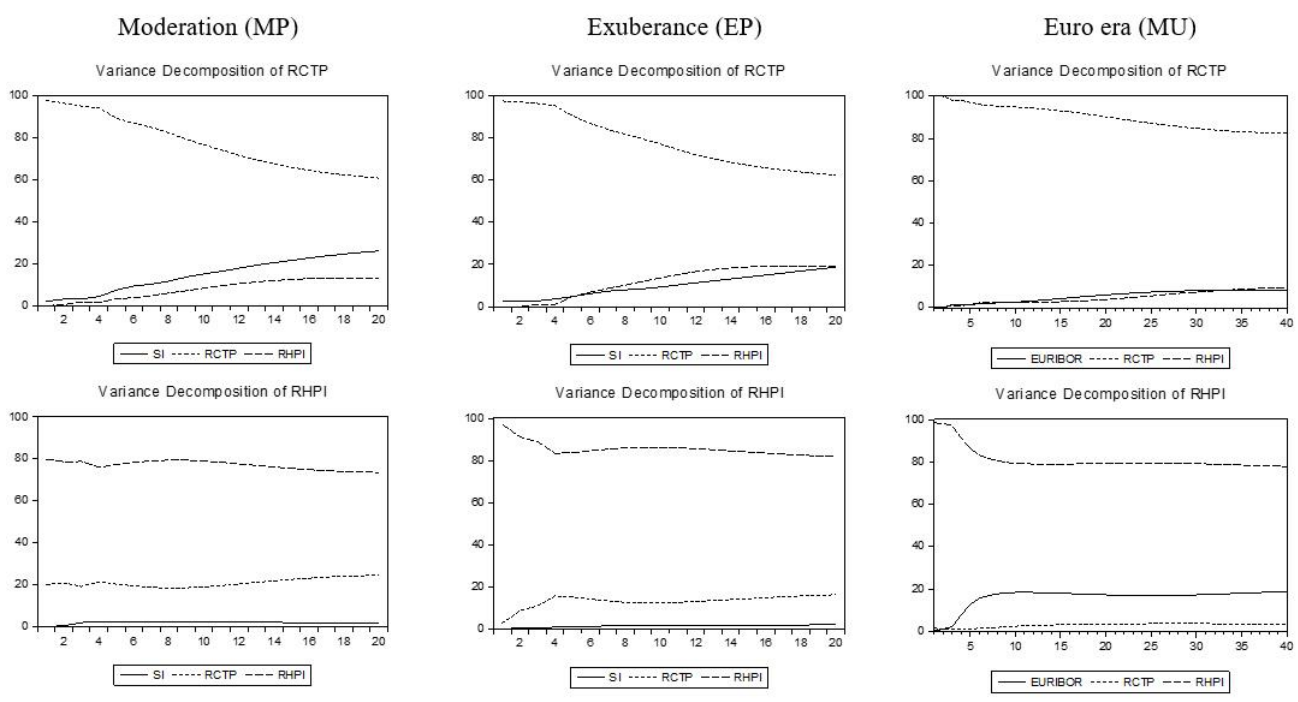

Source: Own computations.

\subsection{Extension of the model}

After reviewing the empirical results, the most salient difference between the Euro era and the other intervals is the substantial change in driving forces contributing to house price developments. In addition, according to the impulse response results, the interest rate in the Euro era period has no statistically significant 
impact on credit activity. Furthermore, house prices appear to be not dependent from the outstanding private credit any longer. In order to reveal the origin of the significant change in the transmission mechanisms in the Euro era, I decided to replace the time series of real outstanding total credit to private sector by other type of credit aggregate. Since after the Euro accession the country experienced a massive surge in mortgage lending activity partly due to innovations and deregulations on mortgage markets as for example the securitization, its proportion in respect to the total credit outstanding to the private sector had increased prominently (Graph 6). From this perspective, it is reasonable to estimate the model with the real outstanding aggregate mortgage credit.

\section{Graph 6. Mortgage credit to total outstanding credit to private sector}

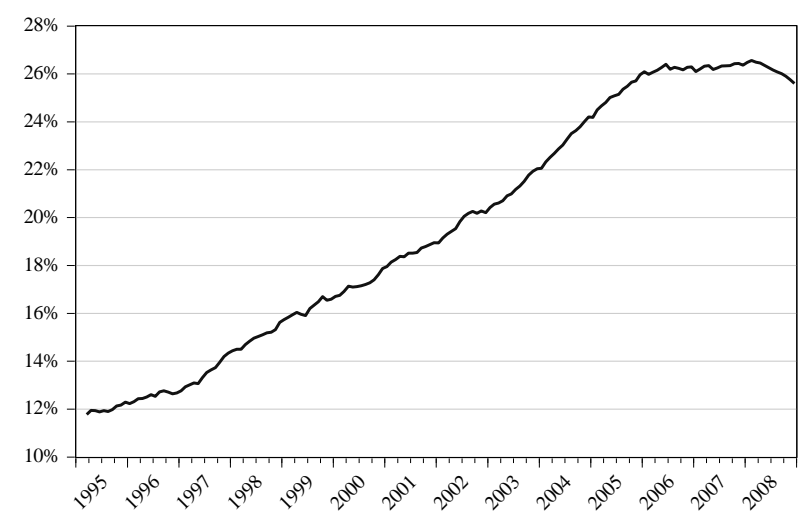

Source: BDE, own editing.

The modified VAR estimation is based on the following model which comprises the two unchanged variables (short-term nominal interest rate and log difference of real house price index, si and $\Delta r h p i$ respectively) and newly introduced log difference of real outstanding total mortgage to private sector $(\Delta r m o r t)$.

$$
y_{t}=[\text { si, } \Delta \text { rmort, } \Delta r h p i]^{T}
$$

Wald Test (Table 4 ) shows that the house price became the explanatory variable and the $p$ value (0.0155) indicates that it Granger causes a change in mortgage credit. 
The effects of monetary policy on house prices in Spain

Table 4. VAR Granger causality/block exogeneity Wald tests

\begin{tabular}{|c|c|c|c|}
\hline \multicolumn{3}{|l|}{ Dependent variable: RMORT_SALD } & \\
\hline Excluded & Chi-sq & df & Prob. \\
\hline EURIBOR & 7.043206 & 3 & $\mathbf{0 . 0 7 0 5}$ \\
\hline RHPI & 10.39284 & 3 & $\mathbf{0 . 0 1 5 5}$ \\
\hline All & 20.04182 & 6 & $\mathbf{0 . 0 0 2 7}$ \\
\hline
\end{tabular}

Source: Own computations.

Graph 7. Accumulated impulse responses to Cholesky One S.D. Innovations (Model Extension)

Accumulated Response to Cholesky One S.D. Innovations \pm 2 S.E.

Accumulated Response of RMORT

to EURIBOR

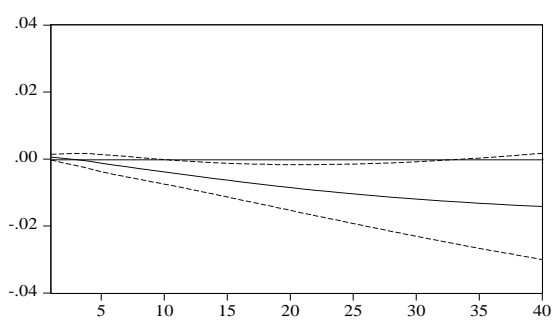

Accumulated Response of RMORT to RHPI

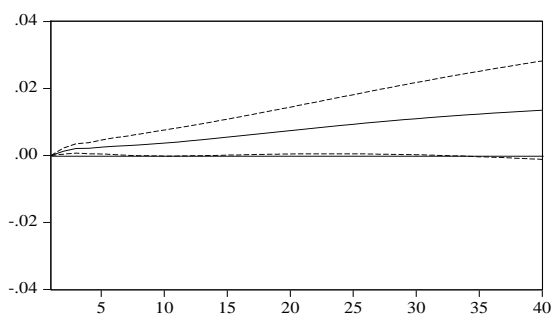

Accumulated Response of RHPI to RMORT

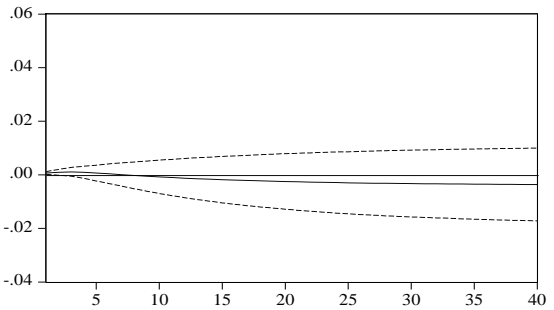

Source: Own computations. 
In respect to the result of impulse responses, Graph 7 displays that the EURIBOR rate inversely effects mortgage lending. According to the confidence band the impact becomes significant after the ninth month (third quarter) and last until the end of the third year. House price also has a significant influence on the outstanding mortgage credit from the first month until the end of the third year. The response of property prices to the change of mortgage credit also turns out to be significant in the first three months, however, its response function is low.

\section{Discussion}

This section draws a conclusion from the empirical results obtained in the three analysed intervals with the guideline of the theoretical background discussed in the second chapter. The synthesis expected to identify the most relevant links between monetary policy and house price developments. To this purpose the analysis reconciles the VAR model outputs with the concepts of transmission channels, taking into consideration the time varying peculiarities of the Spanish economy. Since the analysis covers multiple intervals, the evaluation also expected to determine the evolution of the transmission mechanism effecting house price alterations.

On the basis of the empirical outputs, summarized in Table 2, the change of transmission linkage over the analysed interval is evident. At the beginning of the "Moderation" period, which takes place between 1975 and the Euro accession in 1999, the Spanish economy was exposed to a considerably volatile economic setting characterized by relatively high interest rates and a high inflation rate. Throughout the interval, the two indicators had a downward tendency and at the end of the period they moderated substantially with a mitigated fluctuation. The steady improvement in these key monetary factors was accompanied by a gradual advancement in the regulatory environment with an integrative process toward the EMU accession. As the key legislative innovations affecting the funding structure of the financial intermediaries occurred at the end of the period, the prevalent attribute was a rather 
immature banking structure where the private banks played a less significant role. ${ }^{28}$ The evaluation of the empirical results suggests that in this interval the credit channel was the primary way of causality between the monetary policy and house prices. Although Bernanke and Gertler (1995) and Kashyap et al. (1993) point to the high practical difficulty involved in conducting an empirical analysis aimed at identifying the exact way of monetary transmission under the credit channel, there are numerous theoretical and fewer empirical studies in the literature which provide support for further specification. Bernanke and Gertler (1995) argue that an economy characterized by a limited bank funding structure and a less liquid and less developed market for bank liabilities mitigates the importance of the bank lending channel. Iacoviello and Minetti (2007) also emphasize that in countries where mortgage securitisation is not developed, the bank lending channel is more relevant. Boivin et al. (2010) underline the importance of the bank lending channel in economies where borrowers are more dependent on bank loans. These features largely fit the Spanish mortgage market in the "Moderation" phase, when the traditional bank lending was dominant and its role was crucial in financing private sector investments and expenditures. In addition, the empirical results of Iacoviello and Minetti (2007) also show the significant function of the bank lending channel in countries where mortgage finance is more bank dependent. ${ }^{29}$ According to the empirical results combined with the theoretical base, the most relevant way of causality on the basis of bank lending channel is the following. The expansionary monetary policy, through rising bank reserves and bank deposits, shifted the supply of credit aggregates. Because many borrowers are dependent on bank loans to finance house purchases, this expansion resulted in house price inflations.

The "Exuberance" period accounts for the interval between 1985 and the onset of GFC in 2008. After 1985 the real values of house prices and outstanding private credits began to rise intensely which corresponds to the twice experienced housing bubbles (1987-1991 and 1996-2007). The VAR outputs show that the monetary

\footnotetext{
${ }^{28}$ Until the end of 80s a public institution, the Spanish Mortgage Bank was dominating on the mortgage market (Palomera 2014).

${ }^{29}$ Iacoviello and Minetti (2007) tested a credit channel with distinguishing bank lending and balance sheet channels in four European countries' (Finland, Germany, Norway and the UK) housing market by VAR approach.
} 
transmission mechanism associated with the credit view was prevailing as well, while their connections became stronger. Referring to the impulse response function, the impact of a short-term interest rate on credit activity became more persistent but with a weaker effect. Interestingly, the contribution of house prices to credit activity became more robust than the influence of a short-term interest rate. It suggests that the cash-flow channel played a more important role than the bank lending channel.

\section{Table 5. Summary of the empirical findings}

\begin{tabular}{|c|c|c|}
\hline Moderation & Exuberance & Euro era \\
\hline $\mathrm{SI} \rightarrow \mathrm{RCTP} \rightarrow \mathrm{RHPI}$ & $\mathrm{SI} \rightarrow \mathrm{RCTP} \rightarrow \mathrm{RHPI}$ & $\mathrm{SI} \rightarrow \mathrm{RHPI}$ \\
\hline & $\mathrm{RHPI} \rightarrow \mathrm{RCTP}$ & $\mathrm{SI} \rightarrow \mathrm{RCTP}$ \\
\hline & & $\mathrm{SI} \rightarrow \mathrm{RMORT}$ \\
\hline & & $\mathrm{RHPI} \rightarrow \mathrm{RMORT}$ \\
\hline & & $\mathrm{RMORT} \rightarrow \mathrm{RHPI}$ \\
\hline
\end{tabular}

Source: author's own elaboration

The combined view of the findings connected to the two intervals shows that the key transmission mechanism effecting house price developments was the credit channel in the Spanish economy. The increasing strength of responses with longer persistency in relations and the appearance of a significant collateral effect in the second interval suggest that the factor of expectations and feedback loops became more pertinent. Since these intervals partly overlap, it is hard to make precise implications regarding the change of the transmission mechanism focusing on the period followed by the EMU accession. For this purpose, the empirical estimation, focused solely on the Euro era, provides a more accurate base for further inferences.

The evaluation of the estimation results in the Euro era offers an essentially different view. The main driving force turned out to be the direct impact of a shortterm interest rate on house price inflation. According to the VAR impulse function the response of house prices for interest rate innovation is sharp and lasts over 2 years. The reconciliation of the result with the theoretical base suggests that the traditional interest rate channel became the major link between the monetary policy and house prices in the Euro era. There are multiple ways in which the traditional 
interest rate channel materializes in house price inflations. However, considering the low level of the real interest rate - which was negative during the most intense surge in property prices before 2006 as a result of the low ECB's policy rates, apparent in Graph 1 - the cost of capital approach appears to be the leading factor in the transmission causalities. Regarding the credit channel, the transmission mechanism appears to be weaker. Although the short-term interest rate influenced private lending, its impact became significant only after 6 quarters, suggested by the impulse response function, with a relatively short persistence. To further explore the credit channel, the empirical results do not indicate any significant impact on the property prices from the private lending activity. This implication corresponds with Edwards and Mishkin (1996), proving that the decline of traditional bank lending made the banks' role less important in credit markets, which eventually rendered the bank lending channel less effective. In addition, the collateral effect also seems to be weaker, only the impulse response suggests positive causality but its extent is insignificant. Considering the modernization progress in the Spanish economy, it is reasonable to conclude that the development in the structure of financial intermediates, especially after the Euro accession, was the main reason for the decreasing importance in the bank lending channel. This finding is in line with the suggestions of Bernanke and Gertler (1995) and Blanchard (2000), as the deregulation process implies a declining relevancy of credit channel.

The substantial changes in the structure of the Spanish credit markets, especially in the mortgage market - occurring primarily during the Euro era - propose a complementary approach as demonstrated in the subsection of model extension. In this manner, the monetary mechanism was analysed with the outstanding mortgage credit. The empirical results suggest that the credit channel is more relevant by focusing solely on mortgage lending activity but its importance is still lower than before the EMU accession. The short-term interest rate effect on mortgage lending appears earlier with more persistency comparing to private credit. In addition, the response of house prices for changes in mortgage credit remains moderately weak with a low degree of persistency. However, the collateral effect was stronger on mortgage lending, which suggests that the channel of balance sheet and wealth effect of households were also relevant during the boom. The result is in line with Souse's 
(2010) empirical finding, which found that monetary policy shocks have a very persistent effect on housing wealth as there is a flight towards assets that are less liquid and earn higher rates of return.

\section{Conclusion}

Considering the reoccurring distortion and adverse economic implications triggered by housing bubbles throughout history, it is crucial to recognise the manner in which this phenomenon evolves and how it is connected to the monetary policy in a given economy. Defining the structure of transmission processes between interest rate policy and house prices is the foremost step for constructing policy interventions aimed at controlling house price developments.

This study discovers the relevant transmission channels between short-term interest rates, credit aggregates and house prices between 1975 and 2008 by applying VAR models. The analysis devotes special attention to the last housing boom, occurring after the accession to the EMU, in order to reveal the importance of the interest rate policy of the ECB in the latest Spanish housing boom.

The theoretical discussion demonstrates that a monetary policy unfolds its effects in various ways in the housing sector, where multiple channels operate simultaneously to various extents. The estimation output of the empirical analysis determines the strength and persistency of the relations between interest rates, credit aggregates and house prices. By reconciling the results with the theoretical models, the study identifies the most dominant channels of the transmission mechanism through multiple phases of the Spanish integration and modernization process. The synthesis reveals that the monetary transmission mechanism in Spain has changed substantially over time since 1975 . At the beginning of the full analysed interval the role of the credit channel was dominant, then, after the development of the credit markets, its importance gradually diminished. After the EMU accession the traditional interest rate channel became the leading factor with an intensified and more persistent effect on house prices. Accordingly, the low interest rate environment played a significant role in the house price expansion during the last 
Spanish housing boom. Thus, the hypothesis of the study is supported: the overly accommodating ECB monetary policy contributed to the emergence of the housing boom which later formed into a bubble. The strong direct linkage between the interest rate and the house prices in the Euro era implies that a more reactive adjustment in the ECB's policy rate could have reduced the magnitude of the Spanish housing bubble.

Despite the significant results of the VAR models, the extraordinarily dynamic expansion in the property prices suggests that the factor of irrational expectations also contributed to the ensuing housing bubble, which was based on the common belief that house prices can increase over a substantial long term with a high rate of increase. However, in the study the empirical analysis underlines that the interest rate policy substantially influences the house prices. Thus, by giving a higher relevance to the house price movements in monetary policy construction, the interest rate policy can support strategies aimed at curbing speculative bubbles in the housing sector.

\section{References}

Akerlof G. (1970), The market for „lemons”. Quality, uncertainty and the market mechanism, „Quarterly Journal of Economics” vol. 84 no. 3, pp. 488-500.

Ambrose B.W., Conklin J., Yoshida J. (2016), Credit rationing, income exaggeration, and adverse selection in the mortgage market, ,Journal of Finance”, vol. 71 no. 6, pp. 2637-2686.

Ando A., Modigliani F. (1963), The „life cycle” hypothesis of saving. aggregate implications and tests, „The American Economic Review”, vol. 53 no. 1, pp. 55-84.

Aoki K., Proudman J., Vlieghe G. (2004), House prices, consumption, and monetary policy. A financial accelerator approach, ,Journal of Financial Intermediation” vol. 13 no. 4, pp. 414-435.

Aspachs-Bracons O., Rabanal P. (2010), The effects of housing prices and monetary policy in a currency union, Monetary Policy Lessons from the Global Crisis, a conference for the International Journal of Central Banking, hosted by the Bank of Japan, 16-17 September 2010.

Ayuso J., Blanco R., Restoy F. (2006), House prices and real interest rates in Spain, Banco de España, Documentos Ocasionales $\quad$ No. 0608 , https://www.bde.es/f/webbde/SES/Secciones/Publicaciones/PublicacionesSeriadas/DocumentosOcasio nales/06/Fic/do0608e.pdf [16.03.2018].

Barth J.R. (2009), The rise and fall of the US mortgage and credit markets. A comprehensive analysis of the Market Meltdown, Wiley \&Sons, Hoboken NJ. 
BDE (nd.), Financiación a los hogares e ISFLSH, residentes en España Ocultar información. https://www.bde.es/webbde/es/estadis/infoest/series/ie0807.csv [17.03.2018].

BDE (nd.), Financiación a los sectores no financieros, residentes en España Ocultar información. https://www.bde.es/webbde/es/estadis/infoest/series/ie0805.csv [17.03.2018].

Bernanke B.S. (1983), Nonmonetary effects of the financial crisis in the propagation of the Great Depression, „The American Economic Review”, vol. 73 no. 3, pp. 257-276.

Bernanke B.S., Blinder A.S. (1992), The federal funds rate and the channels of monetary transmission, „The American Economic Review”, vol. 82 no. 4, pp. 901-921.

Bernanke B., Gertler M. (1989), Agency costs, net worth, and business fluctuations, „The American Economic Review", vol. 79 no. 1, pp. 14-31.

Bernanke B.S., Gertler M. (1995), Inside the black box. The credit channel of monetary policy transmission, „Journal of Economic Perspectives”, vol. 9 no. 4, pp. 27-48.

Bernanke B.S., Gertler M., Gilchrist S. (1996), The financial accelerator and the flight to quality, „Review of Economics and Statistics”, vol. 78 no. 1, pp. 1-15.

BIS (nd.), Credit to the non-financial sector, https://www.bis.org/statistics/totcredit/totcredit.xlsx [17.03.2018].

Bjørnland H., Jacobsen D.H. (2010), The role of house prices in the monetary policy transmission mechanism in small open economies, „Journal of Financial Stability”, vol. 6 no. 4, pp. 218-229.

Bjørnland H., Jacobsen D.H. (2013), House prices and stock prices: different roles in the US monetary transmission mechanism, „The Scandinavian Journal of Economics”, vol. 115 no. 4, pp. 1084-1106.

Blanchard O. (2000), What do we know about macroeconomics that Fisher and Wicksell did not? „NBER Working Paper”, no. 7550, http://www.nber.org/papers/w7550.pdf [17.03.2018].

Blanchard O., Perotti R. (2002), An empirical characterization of the dynamic effects of changes in government spending and taxes on output, „Quarterly Journal of Economics”, vol. 17 no. 4, pp. 13291368.

Boivin J., Kiley M.T., Mishkin F.S. (2010), How has the monetary transmission mechanism evolved over time?, „NBER Working Paper”, no. 15879, http://www.nber.org/papers/w15879.pdf [17.03.2018].

Boldin M.D. (1994), Dating turning points in the business cycle, ,The Journal of Business”, vol. 67 no. 1, pp. 97-131.

Brayton F., Marquez J. (1990), The behavior of monetary sectors and monetary policy. Evidence from multicountry models, in: Financial sectors in open economies, „Empirical Analysis and Policy Issues”, Hooper P., Johnson K., Kohn D., Lindsey D., Porter R., Tryon R. (ed.), Board of Governors of the Federal Reserve System, Washington, DC, pp. 365-393.

Brooks C. (2008), Introductory econometrics for finance, 2nd edition, Cambridge University Press, Cambridge. 


\section{The effects of monetary policy on house prices in Spain}

Camarero M., Ordonez J., Tamarit C. (2002), Monetary transmission in Spain. A structural cointegrated VAR approach, „Applied Economics”, vol. 34 no. 17, pp. 2201-2212.

Carbó S., Marqués D., Rodríguez F. (2011), Securitization, bank lending and credit quality. The case of Spain, „ European Central Bank Working Paper" no. 1329, https://www.ecb.europa.eu/pub/pdf/scpwps/ecbwp1329.pdf?edea6b67b04983db231a8c9726f10e60 [17.03.2018].

Case K.E., Quigley J.M, Shiller R.J. (2001), Comparing wealth effects. The stock market versus the housing market, „University of California, Berkeley, Institute of Business and Economic Research Papers", no. W01-004, https://urbanpolicy.berkeley.edu/pdf/CQSAdvMacro2005Web.pdf.

Ciccarelli M., Maddaloni A., Peydró J.-L. (2013), Heterogeneous transmission mechanism. Monetary policy and financial fragility in the Eurozone, „Economic Policy”, vol. 28 no. 75, pp. 459-512.

Clarida R., Galí J., Gertler M. (1998), Monetary policy rules in practice. Some international evidence, „European Economic Review”, vol. 42 no. 6, pp. 1033-1067.

Clarida R., Galí J., Gertler M. (1999), The science of monetary policy. A new Keynesian perspective, „Journal of Economic Literature”, vol. XXXVII, pp. 1661-1707, https://www.nyu.edu/econ/user/gertlerm/science.pdf [17.03.2018].

Cuestas J. (2017), House prices and capital inflows in Spain during the boom. Evidence from a cointegrated VAR and a structural Bayesian VAR, „Journal of Housing Economics”, vol. 37 no. C, p. $22-28$.

Dokko J., Doyle B.M., Kiley M.T., Kim J., Sherlund S., Sim J., Heuvel S.V.D. (2011), Monetary policy and the global housing bubble, „Economic Policy”, vol. 26 no. 66, pp. 237-287.

Edwards F.R., Mishkin F.S. (1995), The decline of traditional banking. Implications for financial stability and regulatory policy, „Economic Policy Review”, vol. 1 no. 2, pp. 27-45.

Esteban M., Altuzarra A. (2008), A model of the Spanish housing market, „Journal of Post Keynesian Economics", vol. 30 no. 3, pp. 353-373.

European Central Bank (ECB), Statistical Data Warehouse (2017), Key ECB interest rates, http://sdw.ecb.europa.eu/reports.do?node=10000025 [17.03.2018].

Fernández F., Hernández P. (2006), The economic effects of exogenous fiscal shocks in Spain a SVAR approach, " European Central Bank Working Paper Series", no. 647, https://www.ecb.europa.eu/pub/pdf/scpwps/ecbwp647.pdf?3e4118a7163b8715420841c2380bf8d3 [17.03.2018].

Fernández N.D. (2016), La crisis económica española. Una gran operación especulativa con graves consecuencias, „Estudios Internacionales”, vol. 48 no. 183, pp. 119-151.

Findley D.F., Monsell B.C., Bell W.R., Otto M.C., Chen B.-C. (1998), New capabilities and methods of the X-12-ARIMA Seasonal-Adjustment Program, „Journal of Business \& Economic Statistics”, vol. 16 no. 2 , pp. $127-152$.

Fisher I. (1933), The Debt Deflation Theory of Great Depressions, „Econometrica”, pp. 337-57. 
Friedman M. (1957), A theory of the consumption function, Princeton University Press, Princeton.

Gali J. (1999), Technology, employment, and the business cycle. Do technology shocks explain aggregate fluctuations?, „The American Economic Review”, vol. 89 no. 1, pp. 249-271.

Gattini L., Ganoulis I. (2012), House price responsiveness of housing investments across major European economies, „European Central Bank Working Paper Series”, no. 1461, https://www.ecb.europa.eu/pub/pdf/scpwps/ecbwp1461.pdf?e89b2ad7eaac33bc4443714f28caa81b [17.03.2018].

Gerlach S., Peng W. (2005), Bank lending and property prices in Hong Kong, „Journal of Banking and Finance", $\quad$ vol. $29, \quad$ pp. http://citeseerx.ist.psu.edu/viewdoc/download;jsessionid=F8BC22D21FBBEE22071FF9580C07160B? doi=10.1.1.511.5905\&rep=rep1\&type=pdf [17.03.2018].

Gimeno R., Martínez-Carrascal C. (2010), The relationship between house prices and house purchase loans. The Spanish case. „Journal of Banking \& Finance”, vol. 34 no. 8, pp. 1849-1855.

Goodfriend M., King R.G. (1997), The new neoclassical synthesis and the role of monetary policy, „NBER Macroeconomics Annual”, vol. 12, B.S. Bernanke, J.J. Rotemberg (ed.), pp. 493-530, http://www.nber.org/chapters/c11040.pdf [17.03.2018].

Goodhart C., Hofmann B. (2008), House prices, money, credit, and the macroeconomy, „Oxford Review of Economic Policy", vol. 24 no. 1, pp. 180-205.

Greene W.H. (2002), Econometric analysis, 7th edition, Pearson Education, New York.

Harris E.S., Boldin M.D., Flaherty M. (1994), The credit crunch and the construction industry, Federal Reserve Bank of St. Louis, https://fraser.stlouisfed.org/files/docs/publications/credit/pages/19901994/28741_1990-1994.pdf [17.03.2018].

Hayashi F., (1982), Tobin's marginal q and average q. A neoclassical interpretation, „Econometrica”, vol. 50 no. 1., pp. 213-224.

Higgins M., Osler C., (1997), Asset market Hangovers and Economic Growth: The OECD during 1984-93, „Oxford Review of Economic Policy”, Vol. 13, pp. 110-134.

Hubbard R.G. (1995), Is there a „credit channel” for monetary policy?, „Review 77 Federal Reserve Bank of St. Louis", vol. 77 no. 3, pp. 63-77.

Hunter W.C., Kaufman G.G., Pomerleano M. (2003), Asset price bubbles. The implications for monetary, regulatory, and international policies, MIT Press, Cambridge, MA.

Iacoviello M. (2005), House prices, borrowing constraints and monetary policy in the business cycle, „American Economic Review”, vol. 95 no. 3, pp. 739-764.

Jarociński M., Smets F. (2008), House prices and the stance of monetary policy, , European Central Bank. Working Paper Series”, https://www.ecb.europa.eu/pub/pdf/scpwps/ecbwp891.pdf?ebb33813f3e5610a5a39285e5c31923d [17.03.2018]. 


\section{The effects of monetary policy on house prices in Spain}

Jorgenson D. (1963), Papers and proceedings of the Seventy-Fifth Annual Meeting of the American Economic Association, „The American Economic Review”, vol. 53 no. 2, pp. 247-259.

Kashyap A., Stein J., Wilcox D. (1993), Monetary policy and credit conditions. Evidence from the composition of external finance, „American Economic Review”, vol. 83 no. 1, pp. 78-98.

Keynes J.M. (1936), The general theory of employment, interest and money, Macmillan and Co., London.

Kiyotaki N., Moore J. (1997), Credit cycles, „Journal of Political Economy”, vol. 105 no. 2, pp. 211248.

López J.R. (2017), Las viviendas que pudieron hundir la economía Española, „La caída del mercado de vivienda y sus consecuencias. Cuadernos de relaciones laborales”, vol. 35 no. 1, pp. 71-99.

Ludwig A., Sløk T. (2001), The impact of changes in stock prices and house prices on consumption in OECD Countries, „IMF Working Paper”, no. https://www.imf.org/en/Publications/WP/Issues/2016/12/30/The-Impact-of-Changes-in-Stock-Pricesand-House-Priceson-Consumption-in-OECD-Countries-15554 [17.03.2018].

Ludwig A., Sløk T. (2004), The relationship between stock prices, house prices and consumption in OECD countries, ,Topics in Macroeconomics”, vol. 4 no. 1.

Mack A., Martínez-García A. (2011), A cross-country quarterly database of real house prices. A methodological note, „Globalization and Monetary Policy Institute Working Paper”, no. 99, https://www.dallasfed.org/ /media/documents/institute/houseprice/hp1601.xlsx [17.03.2018].

McCallum B.T., Nelson E. (1999), An optimizing IS-LM specification for monetary policy and business cycle analysis, „Journal of Money, Credit, and Banking”, vol. 31 no. 3, pp. 296-316.

Mishkin F.S. (1996), The channels of monetary transmission. Lessons for monetary policy, „Banque de France: Bulletin. Digest", no. 27, pp. 33-44.

Modigliani F. (1971), Monetary policy and consumption, in: Consumer spending and monetary policy. The linkages. Proceedings of Monetary Conference, June 1971, Federal Reserve Bank of Boston, Boston, pp. 9-98.

Modigliani F., Brumberg R. (1955), Utility analysis and the consumption function. An interpretation of cross-section data „Post-Keynesian Economics Rutgers University Press”, pp. 388-436.

OECD (nd.), Gross domestic product GDP, https://data.oecd.org/gdp/gross-domestic-product-gdp.htm [17.03.2018].

OECD (nd.), Inflation CPI, https://data.oecd.org/price/inflation-cpi.htm [17.03.2018].

OECD (nd.), Short-term interest rates, https://data.oecd.org/interest/short-term-interest-rates.htm [17.03.2018]. 
Palomera J. (2013), How did finance capital infiltrate the world of the urban poor? Homeownership and social fragmentation in a Spanish neighborhood, „International Journal of Urban and Regional Research", vol. 38 no. 1, pp. 218-235.

Romer C.D., Romer D.H. (1989), Does monetary policy matter? A new test in the spirit of Friedman and Schwartz, „NBER Macroeconomics”, vol. 4, pp. 121-184.

Romero M. (2014), Demand for second homes in Spain SEFO, „Spanish Economic and Financial Outlook", vol. 3 no. 6 , pp. 73-78.

Runkle D.E. (1987), Vector autoregressions and reality, „Journal of Business and Economic Statistics”, vol. 5, no. 4, pp. 437-442.

Sargent T.J., Sims C.A. (1991), Empirical macroeconomics, „Nobel Prize Committee in its series Nobel Prize in Economics documents with number 2011-2", https://www.nobelprize.org/nobel_prizes/economic-sciences/laureates/2011/advancedeconomicsciences2011.pdf [17.03.2018].

Shiller R.J. (2000), Irrational exuberance, Princeton University Press, Oxford.

Sims C.A. (1980), Macroeconomics and reality, „Econometrica”, vol. 48 no. 1, pp. 1-48.

Souse R.M. (2010), Housing wealth, financial wealth, money demand and policy rule. Evidence from the Euro area, „The North American Journal of Economics and Finance”, vol. 21 no. 1, pp. 88-105.

Stiglitz J., Weiss A. (1981), Credit rationing in markets with imperfect information, „American Economic Review", vol. 71 no. 3, pp. 393-410.

Stock J.H., Watson M.W. (1999), Business cycle fluctuations in U.S. macroeconomic time series, „NBER Working Series”, no. 6528, http://www.nber.org/papers/w6528.pdf [17.03.2018].

Taylor J.B. (1995), The monetary transmission mechanism. An empirical framework, „Journal of Economic Perspectives", vol. 9 no. 4, pp. 11-26.

Tobin J. (1969), A general equilibrium approach to monetary theory, ,Journal of Money, Credit and Banking", vol. 1 no. 1, pp. 15-29. 